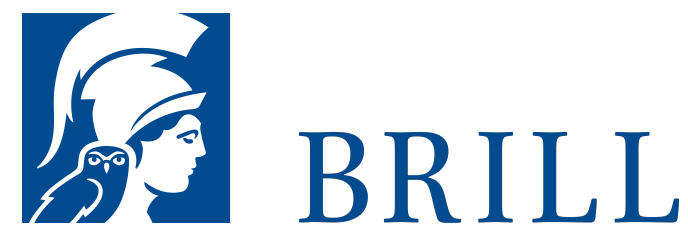

\title{
A Dialogical Concept of Minority Rights
}

\section{Author: Hanna H. Wei}

In A Dialogical Concept of Minority Rights, Hanna H. Wei demonstrates that a more plausible and realistic concept of minority rights should consist of not only rights against the state but also rights against the group. She formulates and defends three separate but related rights to dialogue, and thoroughly analyses how they may operate not only to maintain a healthy balance between the minorities' need to be culturally distinct and their need to relate to and belong in the larger society, but also that they address the generalisations and presuppositions on which the debate of multiculturalism has been based, and constitute the first step of a possible solution to many of the theoretical and practical difficulties of minority protection.

\section{Readership}

Human and minority rights academics, researchers, postgraduate students, practitioners, policy makers, academic libraries, and NGOs.

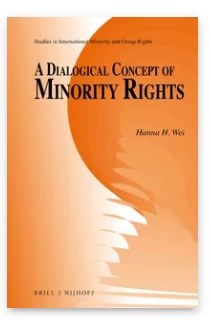

Pages: xvi, 26o

pp.

Language:

English

Subjects:

Human Rights, Human Rights and

Humanitarian

Law, Minority \& Group Rights, Human Rights and

Humanitarian Law, Legal Philosophy, Philosophy, Social \&

Political

Philosophy,

Philosophy,

Cultural Studies, Social Sciences

Publisher: Brill | Nijhoff

Series:

Studies in

International

Minority and

Group Rights,

Volume: 11

E-Book (PDF)

Released online: 26 Apr 2016 
ISBN: $978-90-$

04-31204-3

List price

Hanna H. Wei, Ph.D. (Bristol), is Associate Professor at the Law

USD $\$ 223.00$

School of Shandong University, China. Her research interests are legal and political philosophy, human and minority rights.

Hardback

Publication date:

12 May 2016

For more information see brill.com

ISBN: $978-90-$

04-312O3-6

List price

Order information: Order online at brill.com

USD $\$ 223.00$

Submission information: brill.com/authors

Titles published by Brill | Fink, Brill | mentis or Brill | Schöningh: +49(o)71 5413279216 | brill@brocom.de 